\title{
Studi On Person Over Board dalam Pendidikan dan Pelatihan Maritim di Polimarin Semarang
}

\author{
P Tony Kusumartono ${ }^{1)}$, Hero Budi Santoso ${ }^{2)}$, Noviarianto ${ }^{3)}$ \\ Politeknik Maritim Negeri Indonesia \\ Jl. Pawiyatan Luhur I/I Bendan Dhuwur Kota Semarang, Indonesia 50233 \\ Email : ${ }^{1)}$ tony@polimarin.ac.id, ${ }^{2}$ herobudi@polimarin.ac.id, ${ }^{3)}$ novi@polimarin.ac.id
}

\begin{abstract}
Abstrak
Orang Jatuh ke Laut, Person Over Board (POB) adalah salah satu keadaan darurat yang masih sering terjadi diatas kapal, seorang penumpang atau awak kapal jatuh ke laut. Situasi ini sangat berbahaya jika terjadi di tengah lautan atau di perairan dingin karena hipotermia yang dapat menyebabkan ketidaksadaran dan kematian dalam beberapa menit saja. Penelitian ini fokus terhadap investigasi peningkatan respon para mahasiswa politeknik pada saat keadaan darurat yaitu Orang Jatuh kelaut (POB) dengan dukungan pelatihan pembelajaran manouver onboard di Bridge Simulator serta pengambilan keputusan tindakan bermanuver kapal yang aman dan tepat dalam tindakan penyelamatan POB. Penelitian ini menggunakan metode deskriptif untuk menilai pelatihan olah gerak kapal khususnya orang jatuh ke laut (POB) di antara mahasiswa politeknik maritim negeri Indonesia, yang dirancang bagi para mahasiswa dan peneliti untuk mengumpulkan informasi tentang kondisi yang diperlukan dalam bidang studi nautika. Percobaan beberapa tindakan putaran penyelamatan (rescue turn) Anderson, Williamson dan Scharnow model dilakasanakan di simulator radar dan arpa, respon mahasiswa dengan dukungan manual maneuver on board dan data olah gerak kapal yang meliputi waktu, jarak, kecepatan dan arah kapal atau sudut baringan. Ketepatan respon mahasiswa yang dilakukan pada saat keadaan darurat POB tidak selalu sesuai dengan instruksi yang ada dalam manual manouver on board. Kesalahan-kesalahan terjadi pada bagian awal manuver yang bisa berarti menimbulkan dampak negatif yang membahayakan keselamatan POB. Tindakan manuver kapal yang aman dan tepat dalam keadaan POB dipengaruhi oleh faktor waktu kejadian dan kapan POB diketahui.
\end{abstract}

Kata kunci: Person Over Board, Hipotermia, Manuver, Rescue Turn

\begin{abstract}
Person Over Board (POB) is one of the emergencies that still occurs on board, a passenger or crew member falls into the sea. This situation is very dangerous if it occurs in the middle of the ocean or in cold waters because of hypothermia which can cause unconsciousness and death within minutes. This research focuses on investigating the improvement of the response of polytechnic students during emergencies, namely Person over board (POB) with the support of manouver onboard training in Bridge Simulator as well as making decisions on safe maneuvering and precise ship response manouvre in POB rescue actions. This study uses descriptive methods to assess ship manouvre training especially when person over board (POB) among Indonesian maritime polytechnic students, which are designed for students and researchers to gather information about the conditions needed in the field of nautical studies. The rescue attempts of the Anderson, Williamson and Scharnow model of rescue turn are carried out in radar and arpa simulators, student responses with the support of manual maneuvers on board and vessel motion data which include time, distance, speed and direction of the ship or angle of target bearing. The accuracy of student responses made during a POB emergency does not always comply with the instructions in the Manouvre on Board manual. Errors occur at the beginning of the maneuver which could mean a negative impact that endangers POB safety. Safe and precise ship maneuverability in the POB situation is influenced by the time factor of the incident and when the POB is known.
\end{abstract}

Key words: Person Over Board, Hipotermia, Manuver, Rescue Turn. 


\section{PENDAHULUAN}

Salah satu keadaan darurat diatas kapal adalah Orang Jatuh ke Laut, Person Over Board (POB) yaitu: seorang penumpang atau awak kapal jatuh ke air. Situasi ini sangat berbahaya jika terjadi di tengah lautan atau di perairan dingin karena hipotermia dapat menyebabkan ketidaksadaran dan kematian dalam beberapa menit saja. Karena itu, jika terjadi Person Over Board (POB) instruksi manuver yang akurat dan andal harus disediakan. Saat ini, kapal semakin dilengkapi dengan sistem navigasi terintegrasi, yang dapat digunakan untuk memberikan pengambilan keputusan cepat dalam situasi seperti itu dan membantu awak kapal dalam prosedur penyelamatan. (IMO, 2014). Pembelajaran di Bridge Simulator, yang dianggap sebagai metode pembelajaran aktif, dibandingkan dengan ceramah kuliah di depan kelas saja. Meskipun pelatihan kapal sebenarnya praktik yang efektif dan sederhana dari isi materi saja tidak mencukupi. Siswa juga harus menampilkan tugas-tugas yang telah diajarkan atau diputuskan di dalam sesi praktik. Selanjutnya, pelatihan yang efektif adalah penting untuk pemikiran aktif dan pemecahan masalah keterampilan. Ditemukan bahwa pelatihan praktik langsung pada pelatihan pelayaran memiliki efek signifikan pada akuisisi keterampilan penanganan kapal.(Kunieda et al., 2019). Dalam hal resiko terhadap kelangsungan kehidupan manusia, keadaan darurat Person Over Board (POB) cukup mengkhawatirkan dan berbahaya karena diperkirakan hanya sekitar 25\% kasus korban selamat dari insiden tersebut. Ada banyak masalah yang membuat operasi penyelamatan menjadi sulit. Pertama, lokasi korban terus bergerak karena ombak, arus, dan angin, yang membuat sulitnya menemukan orang tersebut. Selain itu, peristiwa kecelakaan cenderung terjadi pada malam hari, sedangkan daya tampak (visibility) buruk selanjutnya berkontribusi pada tantangan dalam mendeteksi korban. Selain itu, kecelakaan sering ditemukan dengan tindakan yang tertunda (delay action), sehingga menambah ketidakpastian pada lokasi orang tersebut. (Baldauf et al., 2011), bahkan jatuh dari kapal dengan sendirinya juga sangat berbahaya dan orang-orang telah mengalami cedera serius atau jatuh pingsan karena terkena benturan sehingga tidak sampai ke permukaan air. Untungnya kecelakaan Person Over Board (POB) adalah keadaan darurat maritim yang relatif jarang terjadi dibandingkan dengan, misalnya, kapal kandas dan tabrakan kapal. (Marine Accident Investigation Branch. Southampton, 2014). Dalam manual International Maritime Organization, ada instruksi umum untuk pelaksanaan tiga putaran (turning) penyelamatan yang berbeda, yaitu putaran Anderson (Anderson turn), putaran Williamson (Williamson turn), dan belokan Scharnow (Scharnow turn). Manuver ini memiliki kelebihan dan kekurangan yang berbeda berdasarkan keadaan yang berlaku. Namun, tidak satu pun dari mereka yang mempertimbangkan dinamika spesifik kapal atau keadaan terkini kapal, misalnya kecepatan awal. Kinerja manuver ini telah diuji dengan simulasi dengan berbagai jenis kapal dan hasilnya menunjukkan bahwa manuver umum dapat mengarahkan kapal beberapa ratus meter dari lokasi korban. (Baldauf et al., 2011). Prosedur untuk mengembalikan orang yang jatuh dari laut kembali ke atas kapal tidak dapat berlansung seketika itu juga, karena fakta bahwa kapal atau sekoci penyelamat (rescue boat) tidak dapat diluncurkan dengan aman saat kapal sedang bepergian dengan kecepatan tinggi diatas 7 knots, yang berarti kapal harus melambat secara signifikan. Di sisi lain, jarak perlambatan kapal besar sangat panjang sehingga harus diatur suatu kecepatan yang tepat untuk meluncurkan sekoci penyelamat agar jarak ke korban tidak terlalu besar dan kemudian menempatkan orang dengan sekoci penyelamat akan menjadi tugas yang menantang. Karena itu, respons paling umum terhadap keadaan darurat Person Over Board (POB) adalah melakukan manuver penyelamatan sehingga seluruh kapal kembali kepada orang yang jatuh ke laut tersebut.(Formela, Gil and Ś, 2015).

Penelitian ini fokus terhadap investigasi peningkatan respon para mahasiswa politeknik pada saat keadaan darurat yaitu Orang Jatuh kelaut (POB) dengan dukungan pelatihan manouver onboard di Bridge Simulator. Juga memberikan beberapa solusi-solusi yang ada untuk manuver dukungan serta tambahan yang akan di identifikasi dan didiskusikan melalui metode rubrik. Pendekatan untuk dukungan Pelatihan dengan menggunakan Radar ARPA Simulator yang ada di Politekneknik Maritim Negeri Indonesia yaitu Rheinmetal Defense Electronics, Jerman. Penelitian dan diskusi dilakukan secara khusus untuk kecelakaan Orang Jatuh kelaut (POB).

Tujuan Penelitian untuk mengetahui tingkat respon mahasiswa pada saat keadaan darurat yaitu Orang Jatuh kelaut (POB). Manfaat dari penelitian ini dapat mengantisipasi tindakan yang dilakukan oleh para calon perwira kapal pada saat keadaan darurat, mengetahui jenis-jenis manouver yang dilakukan, dan mengetahui solusi untuk mengurangi timbulnya korban pada kecelakaan kapal orang jatuh ke laut baik pada pelayaran nasional maupun internasional.

Olah Gerak kapal adalah kemampuan sebuah kapal untuk mengubah kedudukannya dari suatu tempat ke tempat lain yang dikehendaki. Kemampuan olah gerak sebuah kapal dipengaruhi gaya-gaya yang bekerja pada kapal, sifat dan posisi gaya itu bekerja serta pengaruh-pengaruh dari dalam kapal yang bersifat tetap dan pengaruh-pengaruh dari luar kapal yang bersifat tidak tetap, diantaranya adalah pengaruh angin, ombak, arus, keadaan perairan dan keberadaan kapal-kapal lain disekitarnya. Pengertian olah gerak dan Pengendalian kapal adalah merupakan suatu hal yang penting untuk memahami beberapa Gaya yang mempengaruhi kapal dalam gerakannya. (Capt.Djoko Subandrijo, 2011) Jadi untuk dapat mengolah gerakkan kapal dengan baik, maka terlebih dahulu harus mengetahui sifat sebuah kapal dan bagaimana gerakannya pada waktu mengolah gerak yang tertentu dan mempelajarinya. 
Tabel 1. Hasil studi terdahulu

\begin{tabular}{ll}
\hline Judul penelitian & \multicolumn{1}{c}{ Hasil } \\
\hline Kunieda et al., 2019 & $\begin{array}{l}\text { Pelatihan praktik langsung pada pelatihan pelayaran } \\
\text { memiliki efek signifikan pada akuisisi keterampilan } \\
\text { penanganan kapal }\end{array}$ \\
\hline & $\begin{array}{l}\text { Keadaan darurat Person Over Board (POB) adalah } \\
\text { keadaan berbahaya karena diperkirakan hanya sekitar } \\
\text { 25\% kasus korban selamat dari insiden POB. Kinerja } \\
\text { manuver ini telah diuji dengan simulasi dengan berbagai }\end{array}$ \\
jaldauf et al., 2011 & $\begin{array}{l}\text { jenis kapal dan hasilnya menunjukkan bahwa manuver } \\
\text { dari lokasi korban }\end{array}$ \\
\hline Formela, Gil and S, & $\begin{array}{l}\text { Respons paling umum terhadap keadaan darurat Person } \\
\text { Over Board (POB) adalah melakukan manuver } \\
\text { penyelamatan sehingga seluruh kapal kembali kepada } \\
\text { orang yang jatuh ke laut tersebut }\end{array}$ \\
\hline
\end{tabular}

Penggunaan alat-alat besar dalam membantu proses maneuver kapal sangat di perlukan dan banyak digunakan saat ini, Bow thruster atau stern thrusters dan controllable pitch propellers (CPP) merupakan contoh dari perangkat yang menjadi pembantu alternatif dalam mengolah gerak kapal yang dikarenakan kemudahan dalam pengoperasian dan pengendalian kapal. Dengan sangat menghargai beberapa bahkan banyak kapal masih banyak yang tidak dilengkapi oleh alat-alat besar pembantu proses olah gerak kapal tetapi tetap harus melaksanakan proses olah gerak kapal .(House, 2015).

Prosedur penyelamatan dapat dibagi menjadi tiga tugas utama. Pertama- tama, situasi dan keadaan orang yang jatuh kelaut (POB) harus diperhatikan dan diumumkan. Kedua, Nakhoda dan awak kapal harus menentukan posisi orang dan manuver penyelamatan (olah gerak) kapal bernavigasi menuju ke orang tersebut. Menyelamatkan orang dari air adalah langkah terakhir dan paling penting. Masing- masing subtugas dalam prosedur penyelamatan memiliki instruksi dan peralatan keselamatan sendiri untuk membantu dalam proses penyelamatan orang jatuh kelaut (POB). (Sevin, 2016).

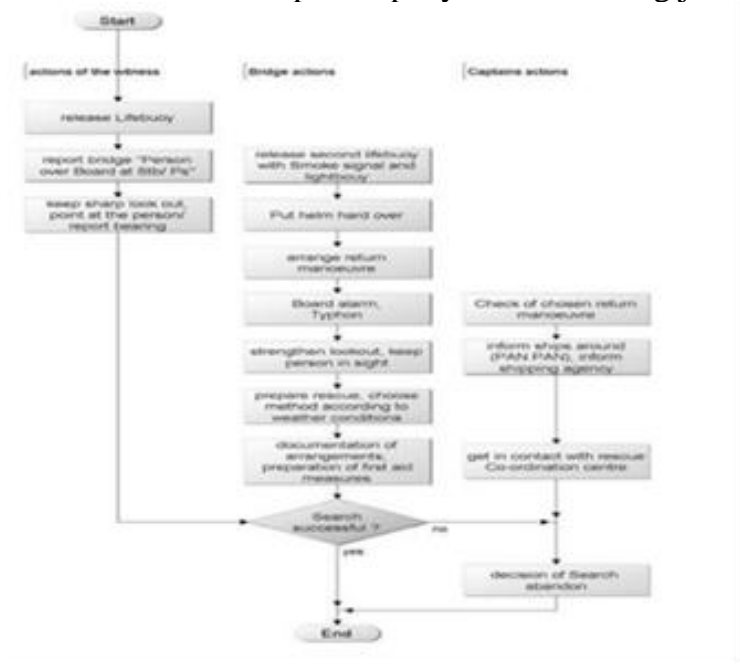

Gambar 1. Flow chart of the rescue procedure used in a POB emergency (Baldauf et al., 2011)

Tiga olah gerak putaran penyelamatan (rescue turn) yang berbeda dalam skenario orang jatuh kelaut (POB) yang diperkenalkan oleh Pencarian dan Penyelamatan Aeronautika dan Maritim Internasional (IAMSAR) dalam manualnya. Perputaran penyelamatan (rescue turn) diketahui adalah, Perputaran Tunggal Anderson (anderson turn), Perputaran Williamson (Williamson turn) dan Perputaran Scharnow (Scharnow turn). Menurut IAMSAR manual, jenis belokan yang berbeda lebih disukai dalam keadaan tertentu, faktor utama adalah waktu yang telah berlalu sejak awal darurat. Dengan demikian, keadaan darurat orang jatuh ke laut (POB) dibagi menjadi tiga kategori yang berbeda berdasarkan keterlambatan mengamati kecelakaan; orang hilang, tertunda atau tindakan segera.(IAMSAR, 2016)

Tindakan segera (immediate action) adalah kasus ketika kecelakaan terdeteksi secara instan oleh anjungan kapal dan prosedur penyelamatan dimulai segera. Posisi POB yang terakhir diketahui didefinisikan dengan baik sehingga manuver harus fokus pada mencapai posisi secepat mungkin. 
Tindakan yang tertunda (delayed action) berarti ada interval pendek antara awal kecelakaan dan inisiasi prosedur penyelamatan. Sebagai contoh, ini bisa disebabkan oleh fakta bahwa informasi berasal dari saksi mata dan bukan dari anjungan itu sendiri dan akibatnya, perlu waktu untuk menginformasikan ke anjungan itu. Dalam hal ini, lokasi korban tidak diketahui, namun, perkiraan lokasi yang layak ada dari riwayat posisi kapal. Manuver yang disarankan dalam kasus tersebut mengembalikan kapal ke jalur timbal baliknya. Hasilnya adalah bahwa kapal tiba ke rute sebelum keadaan darurat, yang merupakan area yang kemungkinan besar POB terletak.

Tindakan pada peristiwa orang yang hilang (person missing actions) adalah kasus-kasus di mana seorang penumpang diketahui hilang di kapal setelah waktu yang signifikan telah berlalu sejak kejadian. Jika, misalnya, insiden itu ditemukan beberapa jam kemudian, kapal itu mungkin telah melakukan perjalanan beberapa ratus kilometer jauhnya dari POB. Dalam hal ini, sering kali tidak mungkin untuk melakukan manuver penyelamatan, tetapi sebaliknya misi pencarian dan penyelamatan (SAR) untuk menemukan POB dimulai.

Waktu bertahan hidup korban sangat bergantung pada suhu air. Jika kecelakaan itu terjadi di perairan dingin, orang tersebut hanya tinggal beberapa menit sebelum menjadi tidak sadar (lihat tabel 1). Setelah diinisiasi, waktu manuver putaran penyelamatan untuk kapal besar mungkin memakan waktu setengah jam untuk diselesaikan, yang menunjukkan betapa pentingnya untuk bereaksi secara instan dan melakukan manuver secepat mungkin (USCG; U.S. Department of Homeland Security., 2003). Tabel 2. 1 menggambarkan suhu air yang berbeda dan waktu kelangsungan hidup yang diharapkan. Waktu bertahan hidup yang tepat bervariasi berdasarkan nilai isolasi tubuh manusia, yang bervariasi berdasarkan ukuran tubuh, usia dan pakaian, misalnya. Jaket dan penyelamat kehidupan pribadi semakin meningkatkan waktu bertahan hidup karena orang yang tenggelam dapat menghindari berenang, yang menghemat stamina dan mengurangi panas yang ditransfer dari tubuh (USCG; U.S. Department of Homeland Security., 2003)

Tabel 2.1 Masa hidup orang dewasa yang diharapkan pada suhu air yang berbeda.

\begin{tabular}{|c|c|c|}
\hline \multicolumn{3}{|c|}{ How Hypothermia Affects Most Adults } \\
\hline Water Temperature ${ }^{\circ} \mathbf{F}\left({ }^{\circ} \mathrm{C}\right)$ & Exhaustion or Unconsciousness & Expected Time of Survival \\
\hline Less than $32.5(0.3)$ & Under 15 min. & Under 15 to $45 \mathrm{~min}$. \\
\hline 32.5 to $40(0.3104 .4)$ & 15 to $30 \mathrm{~min}$. & 30 to $90 \mathrm{~min}$. \\
\hline 40 to $50(4,4$ to 10$)$ & 30 to $60 \mathrm{~min}$. & I to $3 \mathrm{hrs}$. \\
\hline 50 to $60(10$ to 15.6$)$ & 1 to $2 \mathrm{hrs}$. & I $106 \mathrm{hrs}$. \\
\hline $601070(15.61021)$ & $2107 \mathrm{hrs}$. & 21040 hrs. \\
\hline 70 to 80 (21 to 26.7) & 2 to $12 \mathrm{hrs}$ & $3 \mathrm{hrs}$, to indefinite \\
\hline Over $80(26.7)$ & Indefinite & Indefinite \\
\hline
\end{tabular}

\section{METODE PENELITIAN}

Penelitian ini menggunakan metode penelitian kuantitatif yaitu penelitian eksperimental yang dilaksanakan di Bridge dan Radar Arpa Simulator Politeknik Maritim Negeri Indonesi; yaitu eksperimen dilaksanakan untuk menilai pelatihan olah gerak kapal khususnya orang jatuh ke laut di antara mahasiswa politeknik maritim negeri Indonesia, yang dirancang bagi para mahasiswa dan peneliti untuk mengumpulkan informasi tentang kondisi yang ada saat ini yang diperlukan dalam bidang studi nautika.Objek penelitian adalah para peserta di simulator yaitu mahasiswa semester 4 , yang telah lulus pelajaran mata kuliah navigasi dasar dan elektronik navigasi 1, diambil secara acak dari kelas dan terpilih 9 mahasiswa yang akan melaksanakan percobaan beberapa tindakan putaran penyelamatan (rescue turn) yang akan dilakasanakan dan hasil percobaan dan wawancara akan diambil sebagai sumber data.

Penelitian akan dilaksanan di Laboratorium Radar ARPA Simulator milik Polimarin yang berperan sebagai miniatur anjungan yang merupakan tempat pengendalian kapal. Simulator ini dilengkapi sistem penggerak yang terdiri dari Engine Telegraph sebagai pengatur kecepatan dan kemudi serta dilengkapi instrumen-instrumen pendukung, termasuk Electronic Chart Data and Information System (ECDIS). Dengan peralatan-peralatan tersebut dilaksanakan berbagai olah gerak atau manuver menolong Orang Jatuh ke laut serta dilakukan pengambilan data. Data kapal yang digunakan dalam penelitian ini adalah jenis kapal penumpang, kapal container, dan kapal tanker.

Teknik pengumpulan data dilakukan dengan Observasi, wawancara dan dokumentasi. Untuk itu dibentuk tiga grup yang masing-masing terdiri dari tiga mahasiswa. Setiap grup akan melakukan 3 jenis putaran penyelamatan (rescue turn) dengan spesifik dan dengan tipe kapal yang berbeda serta karakteristik kapal yang beda juga. Jenis kapal yang akan digunakankan adalah kapal tanker, kapal container dan kapal penumpang (passenger). Metode dokumentasi dikumpulkan dari pergerakan masing-masing kapal akan diambil data- data hasil olah gerak kapal tersebut sesuai jenis putaran penyelamatan orang jatuh ke laut tersebut (POB). Data yang akan diambil adalah respon mahasiswa dengan dukungan 
manual maneuver on board dan data olah gerak kapal yang meliputi waktu, jarak, kecepatan dan arah kapal atau sudut baringan.

Teknis analisis data yang digunakan dalam penelitian ini adalah analisis data kualitatif. Aktivitas dalam analisis data yaitu data reduction, data display, dan conclusion: drawing/ verification, (Miles and Huberman, 1984).

\section{HASIL DAN PEMBAHASAN}

3.1 Respon Mahasiswa pada saat keadaan darurat (POB) dengan manual manouver on Board.

Tiga grup yang masing-masing terdiri dari tiga mahasiswa yang mengendalikan kapal Aidablu sebuah kapal Penumpang atau kapal Pesiar, Conti Barcelona sebuah Kapal Container dan King Darius yang digunakan untuk mengangkut minyak atau disebut kapal Tanker. Haluan kapal awal yang ditetapkan adalah Utara atau 000 derajad, artinya haluan kapal mengarah dan menuju ke Utara. Kecepatan yang digunakan adalah kecepatan maksimum kapal. Dalam penelitian ini sengaja dirancang tanpa ada pengaruh dari luar kapal yang dapat mempengaruhi olah gerak masing-masing kapal, diantaranya tidak ada pengaruh angin, tidak ada arus dan tidak ada ombak. Kedalaman perairan dipilih di tempat yang memiliki kedalaman antara 35 - 40 meter, yang tidak terdapat rintangan yang mengganggu olah gerak kapal. Masing-masing grup atau kapal melaksanakan tiga (3) jenis putaran seperti yang ditunjukkan pada gambar yaitu, Anderson turn atau Single Turn, Williamson Turn, Scharnow Turn.

Respon mahasiswa dipantau langsung dari tindakan yang mereka ambil selama pelaksanaan dan dari penggalian informasi melalui wawancara di lapangan. Pada peristiwa orang jatuh ke laut dimana mahasiswa berperan sebagai awak kapal yang menyaksikannya, mahasiswa merespon dengan berteriak ke arah anjungan "orang jatuh ke laut di sebelah kanan" sambil melemparkan pelampung penyelamat ke arah korban. Tindakan selanjutnya mahasiswa segera menuju anjungan untuk menginformasikan secara langsung dan lengkap ke anjungan sambil tetap memantau keberadaan korban di air. Respon ini hanya diberikan ketika POB segera diketahui oleh orang kapal yang artinya bisa segera ditemukan dan ditolong dengan didukung olah gerak yang tepat yaitu Anderson Turn atau Single Turn yang merupakan jenis olah gerak menolong orang jatuh ke laut yang paling cepat dan paling sederhana.

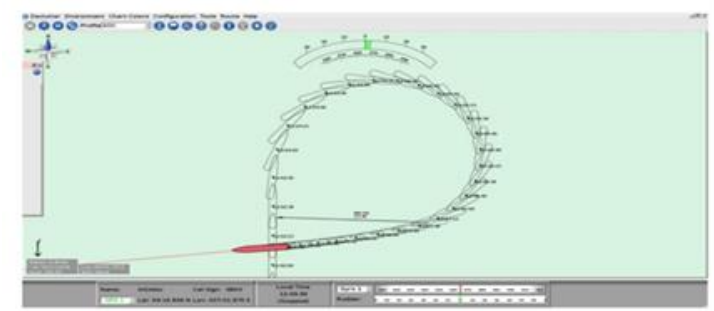

Gambar 2. Gambar dan data rekaman olah gerak Single turn oleh Aidablu

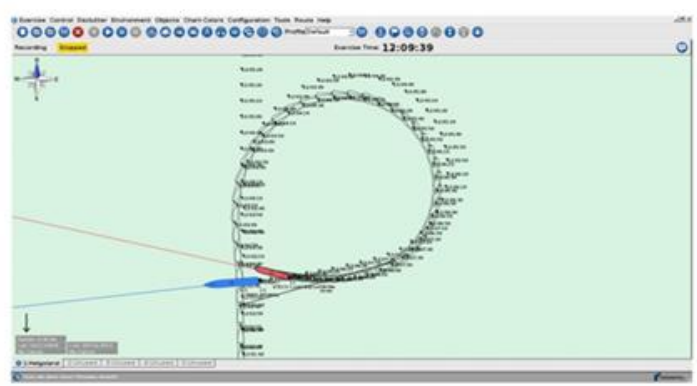

Gambar 3 Gambar dan data rekaman olah gerak Single turn oleh Conti Barcelona

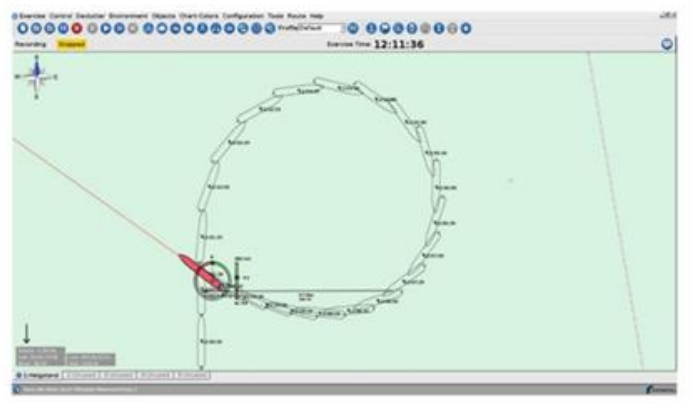

Gambar 4. Gambar dan data rekaman olah gerak Single turn oleh King Darius 
Tabel 2 Respon mahasiswa pada saat keadaan darurat orang jatuh ke laut (POB) Anderson Turn $+$

\begin{tabular}{|c|c|c|c|}
\hline $\begin{array}{l}\text { Respon Mahasiswa } \\
\text { (Single Turn) }\end{array}$ & $\begin{array}{l}\text { Grup Satu (1) } \\
\text { AIDAblu }\end{array}$ & $\begin{array}{l}\text { Grup Dua (2) } \\
\text { Conti } \\
\text { Barcelona }\end{array}$ & $\begin{array}{l}\text { Grup Tiga (3) } \\
\text { King Darius }\end{array}$ \\
\hline $\begin{array}{l}\text { Sebagai awak kapal yang } \\
\text { melihat POB di kapal }\end{array}$ & Ya (Sesuai) & $\mathrm{Xa}_{\mathrm{a}}$ & $\mathrm{Ya}_{\mathrm{a}}$ \\
\hline \multicolumn{4}{|l|}{$\begin{array}{l}\text { Sebagai Penvira Jaga di } \\
\text { Anjungan: }\end{array}$} \\
\hline Kemudi Kanan $20^{\circ}$ & Ya (Sesuai) & $\mathrm{Ya}_{\mathrm{a}}$ & Tidak/ Ya \\
\hline Kemudi Tengah-tengah & Ya (Sesuai) & $\mathrm{Ya}_{\mathrm{a}}$ & $\mathrm{Ya}_{\mathrm{a}}$ \\
\hline Stop Mesin & $\mathrm{Ya}_{\mathrm{a}}$ (Sesuai) & $\mathrm{Ya}_{\mathrm{a}}$ & $\mathrm{Ya}_{\mathrm{a}}$ \\
\hline $\begin{array}{l}\text { Kemudi diarahkan ke } \\
\text { POB }\end{array}$ & $\mathrm{Y}_{\mathrm{a}}$ (Sesuai) & $\mathrm{Ya}_{\mathrm{a}}$ & $\mathrm{X}_{\mathrm{a}}$ \\
\hline
\end{tabular}

Tabel 3 Respon Mahasiswa pada saat keadaan darurat orang jatuh ke laut (POB), Williamson Turn

\begin{tabular}{|c|c|c|c|}
\hline $\begin{array}{l}\text { Respon Mahasiswa } \\
\text { (Williamson Turn) }\end{array}$ & $\begin{array}{l}\text { Grup Satu (1) } \\
\text { AIDAblu }\end{array}$ & $\begin{array}{c}\text { Grup Dua (2) } \\
\text { Conti } \\
\text { Barcelona }\end{array}$ & $\begin{array}{c}\text { Grup Tiga (3) } \\
\text { King Darius }\end{array}$ \\
\hline $\begin{array}{l}\text { Sebagai awak kapal yang } \\
\text { melihat_POB di kapal : }\end{array}$ & Ya (Sesuai) & $\mathrm{Ya}$ & $\mathrm{Ya}$ \\
\hline \multicolumn{4}{|l|}{$\begin{array}{l}\text { Sebagai Perowira Jaga di } \\
\text { Aniungan: }\end{array}$} \\
\hline Kemudi Kanan $20^{\circ}$ & Ya (Sesuai) & $\mathrm{Xa}_{\mathrm{a}}$ & $\mathrm{Xa}_{\mathrm{a}}$ \\
\hline $\begin{array}{l}\text { Kemudi Balas ke kiri } 20^{\circ} \\
\text { (Setelah Haluan berubah } \\
60^{\circ} \text { dari haluan awal) }\end{array}$ & Хa (Sesuai) & $\mathrm{Xa}_{\mathrm{a}}$ & $\mathrm{Xa}_{\mathrm{a}}$ \\
\hline $\begin{array}{l}\text { Kemudi Tengah-tengah } \\
\left(20^{\circ} \text { menjelang arah }\right. \\
\text { Berlawanan dari haluan } \\
\text { Awal) }\end{array}$ & Ya (Sesuai) & $\mathrm{Ya}$ & $\mathrm{Ya}$ \\
\hline $\begin{array}{l}\text { Kemudi diarahkan arah } \\
\text { Berlawanan dari baluan } \\
\text { Awal }\end{array}$ & Ya (Sesuai) & $\mathrm{Ya}_{\mathrm{a}}$ & $\mathrm{Ya}_{\mathrm{a}}$ \\
\hline
\end{tabular}

Tabel 4.Respon Mahasiswa pada saat keadaan darurat orang jatuh ke laut (POB), Scharnow turn

\begin{tabular}{|c|c|c|c|}
\hline $\begin{array}{l}\text { Respon Mahasiswa } \\
\text { (Scharnow Turn) }\end{array}$ & $\begin{array}{l}\text { Grup Satu } \\
\text { (1) } \\
\text { AIDAblu }\end{array}$ & $\begin{array}{l}\text { Grup Dua (2) } \\
\text { Conti } \\
\text { Barcelona }\end{array}$ & $\begin{array}{c}\text { Grup Tiga (3) } \\
\text { King Darius }\end{array}$ \\
\hline \multicolumn{4}{|l|}{$\begin{array}{l}\text { Sebagai Perovira Jaga di } \\
\text { Anjungan: }\end{array}$} \\
\hline Kemudi Kanan $20^{\circ}$ & Ya (Sesuai) & Tidak / Ya & Ya \\
\hline $\begin{array}{l}\text { Kemudi Balas ke kiri } 20^{\circ} \\
\text { (Setelah Haluan berubah } \\
240^{\circ} \text { dari haluan awal) }\end{array}$ & Ya (Sesuai) & $\mathrm{Ya}$ & $\mathrm{Ya}_{\mathrm{a}}$ \\
\hline $\begin{array}{l}\text { Kemudi Tengah-tengah } \\
\left(20^{\circ} \text { menjelang arah }\right. \\
\text { Berlawanan dari haluan } \\
\text { Awal) }\end{array}$ & Ya (Sesuai) & $\mathrm{Ya}_{\mathrm{a}}$ & Ya \\
\hline $\begin{array}{l}\text { Kemudi diarahkan arah } \\
\text { Berlawanan dari haluan } \\
\text { Awal }\end{array}$ & $\mathrm{Ya}$ (Sesuai) & $\mathrm{Ya}_{\mathrm{a}}$ & $\mathrm{Ya}_{\mathrm{a}}$ \\
\hline
\end{tabular}

\subsection{Tindakan manuver kapal dalam keadan orang jatuh ke laut.}

Dari penelitian menggunaakan simulator Radar ARPA ini diambil data dari masing-masing kapal meliputi waktuwaktu pelaksanaan tindakan olah gerak, kecepatan kapal pada kondisi tertentu, sudut baringan dan juga jarak jika dipandang perlu. Pada kesempatan penelitian ini ditetapkan pengambilan data untuk olah gerak putar kiri, artinya hanya akan dilakukan gerakan awal perubahan haluan kapal ke kanan dengan memutar kemudi ke arah kanan dan besaran perubahan kemudi yang ditetapkan adalah dua puluh (20) derajat. 
Tabel 5. Data hasil olah gerak kapal pada saat keadaan darurat orang jatuh ke laut (POB), Anderson Turn

\begin{tabular}{|c|c|c|c|c|}
\hline Action & AidaBlu & $\begin{array}{c}\text { Conti } \\
\text { Barcelona }\end{array}$ & $\begin{array}{c}\text { King } \\
\text { Darius }\end{array}$ & Satuan \\
\hline 1. Starboard 20 (degree) & & & & \\
\hline Time & $12: 02: 30$ & $12: 02: 30$ & 12:01:00 & \\
\hline Speed & 24 & 18.4 & 14.8 & knot \\
\hline $\begin{array}{l}\text { 2. Mid ship and Stop Engine } \\
\text { (Course Change } 250 \\
\text { degree) }\end{array}$ & & & & \\
\hline Time & $12: 07: 26$ & $12: 07: 45$ & 12:07:58 & \\
\hline Speed & 11.4 & 11.2 & 9.3 & Knot \\
\hline $\begin{array}{l}\text { Bearing to initial action } \\
\text { position }\end{array}$ & 272 & 254 & 270 & degree \\
\hline Distance to initial action & 663 & 736 & 87186 & Metre \\
\hline $\begin{array}{l}\text { position } \\
\text { Time Different from starting }\end{array}$ & 663 & 736 & 871.80 & Nateds \\
\hline manoueuxre to mid ship & $0: 04: 56$ & 0:05:15 & $0: 06: 58$ & \\
\hline Crossing the initial course & & & & \\
\hline $\begin{array}{l}\text { Speed } \\
\text { Heading }\end{array}$ & $\begin{array}{r}8.6 \\
253\end{array}$ & $\begin{array}{r}8.4 \\
275\end{array}$ & $\begin{array}{r}6.8 \\
302\end{array}$ & $\begin{array}{l}\text { knot } \\
\text { Degree }\end{array}$ \\
\hline
\end{tabular}

Tabel 6. Data hasil olah gerak kapal pada saat keadaan darurat orang jatuh ke laut (POB), Williamson Turn

\begin{tabular}{|l|r|r|r|l|}
\hline \multicolumn{1}{|c|}{ Action } & AidaBlu & $\begin{array}{c}\text { Conti } \\
\text { Barcelona }\end{array}$ & \multicolumn{1}{|c|}{$\begin{array}{c}\text { King } \\
\text { Darius }\end{array}$} & Satuan \\
\hline $\begin{array}{l}\text { Starboard 20 (degree) } \\
\text { Start time }\end{array}$ & $12: 01: 00$ & $12: 01: 00$ & $12: 01: 00$ & \\
Speed & 22.9 & 18.3 & 14.8 & knot \\
$\begin{array}{l}\text { Port 20 (Course Change 060 } \\
\text { degree) }\end{array}$ & $12: 02: 03$ & $12: 02: 30$ & $12: 03: 02$ & \\
Time & 15.2 & 14.9 & 12.8 & knot \\
Speed & & & & \\
\hline
\end{tabular}

Tabel 7. Data hasil olah gerak kapal pada saat keadaan darurat orang jatuh ke laut (POB), Scharnow Turn

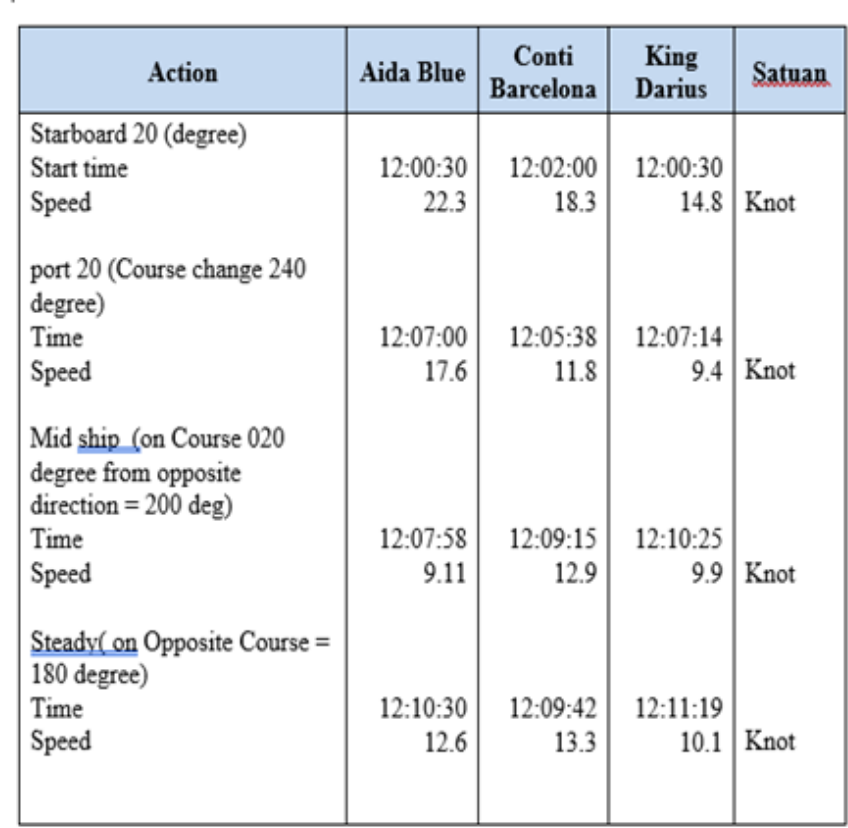




\subsection{PEMBAHASAN}

\subsubsection{Respon mahasiswa dalam keadaan darurat POB menggunakan manuver Anderson/ Single Turn.}

Dari hasil observasi dan wawancara menunjukkan bahwa respon mahasiswa dari masing-masing grup yang berperan sebagai awak kapal yang melihat POB di kapal sudah sesuai Instruksi dan standar penyelamatan keadaan darurat orang jatuh ke laut. Mahasiswa merespon dengan cara segera menginformasikan adanya orang jatuh ke Laut ke pihak Anjungan sambil melemparkan pelampung penolong bagi korban sebagai alat bantu mengapung di laut dan sebagai penanda keberadaan POB. Terdapat perbedaan respon mahasiswa sebagai perwira jaga di anjungan dimana terjadi ketidak sesuaian pada saat harus mengubah kemudi kanan 20 derajad, dimana mahasiswa pemegang kemudi seharusnya memutar kemudi ke kanan sebesar 20 derajad tetapi yang terjadi mahasiswa di kapal King Darius atau kelompok tiga (3) tersebut justru memutar kemudi ke arah kiri. Sementara mahasiswa pada dua (2) kapal yang lain telah bertindak dengan tepat sesuai ketentuan. Kesalahan ini terjadi karena mahasiswa kurang berkonsentrasi dalam melaksanakan gerakan perubahan kemudi. Untuk mendapatkan data akhir dengan membandingkan hasil olah gerak dari masing-masing kapal maka kemudian dilakukan pengulangan simulasi dari awal bagi mahasiswa di grup 3 yang hasilnya dapat memberikan respon dengan benar. Secara keseluruhan maahasiswa dapat merespon dengan olah gerak single turn sesuai dengan ketentuan dengan dukungan manouvre on Board meliputi putaran kemudi 20 derajad kanan sampai haluan kapal berubah arah sebesar 250 derajad lalu kemudi diputar mid ship atau kemudi di posisi tengah-tengah. Selanjutnya kapal diarahkan ke posisi korban di air sembari mengatur kecepatan sesuai situasi riil yang dihadapi.

\subsubsection{Respon Mahasiswa dalam keadaan darurat POB menggunakan manuver Williamson Turn}

Secara keseluruhan, mahasiswa dalam masing-masing grup telah melaksanakan olah gerak sesuai instruksi dengan bantuan manouver on Board baik sebagai awak kapal yang melihat POB di kapal maupun sebagai perwira jaga di Anjungan kapal. Kapal berjalan dengan kecepatan maksimal dengan Haluan Utara atau 000 derajad. Pada saat anjungan menerima informasi orang jatuh kelaut di sebelah kanan, perwira di anjungan segera mengubah haluan ke kanan 20 derajad. Ketika haluan telah berubah sebesar 60 derajad kemudi dibalas atau dibelokkan kea rah berlawanan yaitu kiri 20 derajad sampai haluan 200 derajad kapal meletakkan kemudi di posisi tengah-tengah. Setelah haluan menunjukkan haluan180 derajad yang merupakan arah haluan berlawanan dari haluan awal maka haluan kapal dipertahankan pada haluan tersebut sambil mengamati keberadaan POB untuk sewaktu-waktu segera bisa mengurangi lajunya dan menurunkan sekoci penolong.

\subsubsection{Respon Mahasiswa dalam keadaan darurat POB menggunakan manuver Scharnow Turn}

Dalam penelitian dengan olah gerak Scharnow Turn ini juga terdapat kesalahan yang dilakukan oleh mahasiswa di grup 2 di kapal Conti Barcelona, dimana mereka terlambat bereaksi sehingga ada waktu yang terbuang sia-sia. Padahal dalam operasi pencarian dan penyelamatan adalah harus diusahakan secepat mungkin mengingat bahaya didalam air yang rata-rata adalah lebih dingin dari suhu tubuh manusia yang berpotensi terjadi hypothermia yang dapat mengancam keselamatan jiwa POB. Di luar kesalahan itu mahasiswa dapat memberikan respon yang sesuai dengan maual Manouver on Board , dimulai dari kemudi kanan 20 derajat, kemudi balas kiri 20 derajad pada saat haluan berubah 240 derajat dan kemudi tengah-tengah pada saat haluan 20 derajad menjelang arah berlawanan dengan haluan awal, yaitu pada haluan 200 derajad. Kemudian haluan dipertahankan pada arah 180 derajad yang merupakan opposite course dari haluan awal yaitu Utara atau 000 derajat.

\subsection{Tindakan Manuver Kapal Dalam Keadan Orang Jatuh Ke Laut.}

Tindakan manuver kapal yang pertama dilakukan pada kasus POB yang membutuhkan aksi cepat (Immediate Action) adalah memutar kemudi dengan nilai besar kearah posisi jatuhnya orang di laut. Artinya jika POB di sebelah kanan maka kemudi diputar ke kanan dengan maksud supaya bagian buritan (belakang) kapal segera menjauh dari orang di air tersebut sehingga terhindar dari putaran baling- baling kapal yang sangat membahayakan keselamatan POB. Ketepatan tindakan mengubah kemudi kearah yang tepat adalah sangat penting sebaliknya kesalahan tindakan akan berakibat fatal bagi korban di air, sehingga jika memungkinkan, atau ada person lain yang berada di anjungan sebaiknya turut memantau tindakan pemegang kemudi, bisa secara visual maupun dengan seksama memantau rudder indicator yang dapat menunjukkan pergerakan kemudi. Anderson dan Williamson Turn adalah pilihan yang tepat dalam kasus dimana POB segera diketahui oleh awak kapal. Sementara itu untuk kasus POB yang terlambat diketahui, dimana mungkin waktu kejadian adalah satu jam yang lalu atau bahkan lebih, maka pihak anjungan bebas memutar haluan ke kiri maupun ke 
kanan dengan menyesuaikan kemampuan dan karakteristik kapalnya serta kondisi setempat pada saat itu dengan hasil putaran akhir menghadap kearah berlawanan dari haluan semula untuk kemudian kapal akan menyusuri jalan yang telah dilaluinya dengan harapan dapat menemukan korban jatuh di air di jalan yang sebelumnya telah dilalui. Olah gerak yang dilakukan adalah Scharnow Turn.

Hal ini menunjukkan terjadi penurunan kecepatan kapal hingga turun lebih dari setengah kecepatan maksimum kapal yaitu dari kecepatan pada kapal Aidablu. Penurunan kecepatan kapal terbesar terjadi pada olah gerak Scharnow Turn yaitu $59 \%$, Anderson Turn sebesar 52,5 \% dan pada Williamson Turn sebesar 50,65 \%. Penurunan kecepatan Aidablu pada setiap cara maneuver selalu lebih dari $50 \%$. Setiap penurunan kecepatan yang cukup besar akan mempengaruhi kecepatan penemuan korban yang berarti akan mengurangi peluang hidup korban yang berada di air, namun penurunan kecepatan tersebut tidak bisa dihindari akan terjadi pada setiap kapal yang melakukan perubahan kemudi yang cukup besar dalam jangka waktu yang cukup lama maupun pada gerakan perubahan kemudi yang cukup besar pada arah tertentu yang berulang, contoh pada gerakan maneuver zig zag. Conti Barcelona mengalami penurunan kecepatan sebesar 39,1\% pada Anderson Turn, 38,25 \% pada Williamson Turn dan 35,5\% pada Scharnow Turn. Rata-rata penurunan kecepatan Conti Barcelona pada tiga cara maneuver adalah di atas $35 \%$. Adapun kapal King Darius pada manuver Anserson Turn mengalami penurunan kecepatan sebesar 37,16 \%, Williamson Turn 38,5\% dan Scharnow 36,48 \% atau rata-rsata diatas $36 \%$.

Penelitian menunjukkan bahwa posisi kapal terhadap posisi POB dengan arah haluan kapal tepat menuju korban POB terjadi pada cara manuver Anderson Turn atau Single Turn dan Williamson Turn. Sedangkan dengan cara manuver Scharnow Turn posisi kapal telah melewati posisi POB dengan arah haluan yang menjauh dari korban. Jadi memang benar cara maneuver ini hanya tepat diperuntukkan mencari korban dengan Delay Action artinya tindakan dilakukan beberapa saat setelah dipastikan adanya POB. Kapal Aidablu dengan cara manuver Anderson Turn berjarak sekitar 736 meter dari posisi awal POB dengan arah haluan kapal yang relatif tepat menuju korban. Conti Barcelona berjarak 663 meter dan King Darius berjarak 871,8 meter dari POB. Pada hasil manuver Williamson Turn kapal Aidablu berjarak 1143 meter dari POB, Conti Barcelona 600 meter dan King Darius 800 meter dengan arah yang tepat menuju korban di air.

\section{KESIMPULAN}

Ketepatan respon mahasiswa yang dilakukan pada saat keadaan darurat orang jatuh ke laut (POB) tidak selalu sesuai dengan instruksi yang ada dalam manual Manouvre on Board. Kesalahan-kesalahan terjadi pada bagian awal manuver yang bisa berarti menimbulkan dampak negatif yang membahayakan keselamatan POB. Keberhasilan respon mahasiswa dalam simulasi yang dilakukan dalam penelitian ini dilandasi oleh penguasaan dan penyerapan pengetahuan dari masingmasing mahasiswa yang telah diajarkan di kelas. Selanjutnya perlu diberikan briefing yang tepat sebelum pelaksanaan simulasi, kemudian konsentrasi dan kecermatan dalam pelaksanaan manuver serta faktor yang sangat penting yaitu pengalaman. Terbukti dalam pelaksanaan ulang setelah terjadi kesalahan, mahasiswa mampu melaksanakan tugasnya dengan sempurna.

Tindakan manuver kapal yang aman dan tepat dalam keadaan Orang jatuh kelaut (POB) dipengaruhi oleh faktor waktu kejadian, kapan POB diketahui. Apakah POB langsung diketahui oleh awak kapal atau POB dipastikan setelah beberapa jam kemudian. Dari data tersebut Nakhoda atau perwira kapal dapat menentukan cara manuver yang tepat sesuai kebutuhan.Tindakan manuver yang tepat akan dapat tercapai jika Nakhoda atau perwira kapal yang kompeten dalam arti memiliki pengetahuan yang memadai, terlatih serta bertanggung jawab melaksanakannya dengan penuh konsentrasi dan cermat.Tanpa pengaruh dari luar kapal yang bisa berupa ombak, angin dan arus dalam manuver menolong orang jatuh ke laut mendapatkan hasil tepat seperti dalam teori namun dengan adanya pengaruh dari luar akan menghasilkan pencapaian yang bisa berbeda atau bahkan jauh berbeda. Dengan memperhitungkan faktor pengaruh dari luar kapal tersebut diharapkan akan mencapai keberhasilan walaupun tidak tepat persis seperti hasil dalam teori.

\section{UCAPAN TERIMAKASIH}

Penelitian ini didukung oleh dana BOPTN Politeknik Maritim Negeri Indonesia TA 2019, Terima kasih kepada Ketua LP3M Polimarin dan kepada anggota peneliti dan pembantu peneliti atas partisipasinya

\section{DAFTAR PUSTAKA}

Babicz J, W. and Helsinki, C. (2015) Encyclopedia of Ship Technology, 2nd Edition.

Baldauf, M. et al. (2011) 'e-Navigation and situation-dependent manoeuvring assistance to enhance maritime emergency response', WMU Journal of Maritime Affairs, 10(2), pp. 209-226. doi: 10.1007/s13437-011-0014-x.

Capt.Djoko Subandrijo (2011) Olah Gerak Dan Pengendalian Kapal.

Formela, K., Gil, M. and Ś, H. (2015) 'Comparison of the Efficiency of Williamson and Anderson Turn Manoeuvre’, 9(4), pp. 565-569. doi:10.12716/1001.09.04.14.

House, D.J (2015) Ship Handling, Theori and Practice. 
I.M.O, 2010 ( International Maritime Organisation) (2014) 'Officer in Charge of a Navigational Watch', 44(0), p. 68. I.M.O, M. 1/Circ. 1185/Rev. . 2010 ( I. M. O. (2010) Guide for Cold Water Survival.

IAMSAR, I. M. O. (2016) IAMSAR Manual Volume III.

IMO (2006) MSC.1/Circ.1182, Guide to Recovery Techniques.

Kunieda, Y. et al. (2019) 'Study on effective maritime training through the anchoring training', TransNav, 13(2), pp. 381-386. doi:10.12716/1001.13.02.15.

Kurowski, M., Korte, H. and Lampe, B. P. (2012) AGaPaS - A new approach for search-and-rescue-operations at sea, IFAC Proceedings Volumes (IFAC- PapersOnline). IFAC. doi: 10.3182/20120919-3-IT-2046.00013.

Marine Accident Investigation Branch. Southampton, U. K. (2014) 'Marine Accident Investigation Branch (MAIB). 2011. Annual Report 2010.'

Resolution MSC.81(70), A. 6 (1998) Revised recommendation on testing of life- saving appliances 